\title{
Seasonal Comparison of Potential Groundwater Aquifer in Ijebu-Ife, South-West, Nigeria, using Dipole-Dipole Array and Electromagnetic Methods
}

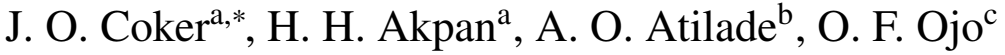 \\ ${ }^{a}$ Department of Physics, Olabisi Onabanjo University, Ago - Iwoye, Ogun State, Nigeria \\ ${ }^{b}$ Department of Physical Sciences, Lagos State Polytechnic, Ikorodu, Lagos State, Nigeria \\ ${ }^{c}$ Department of Geology, Ekiti State University, Ado-Ekiti, Nigeria
}

\begin{abstract}
Seasonal comparison of potential groundwater aquifer unit using integrated geophysical methods at Ijebu-Ife, Ogun State, South-west, Nigeria was investigated. The fieldwork employed two seasons (dry and wet seasons). The electromagnetic method employed the Very low frequency and its data was acquired during the dry and wet seasons along with five profiles of Dipole-dipole array covering $500 \mathrm{~m}$ length using ABEM WADI VLF equipment and was processed using the KAROUS-HJELT software. The 2 - D Dipole-dipole data were also acquired along with five (5) traverse for both seasons making a total number of ten (10) and was processed with DIPROFWIN software. The results of the Integrated Dipole-Dipole and VLF-EM data identified three geoelectric layers based on its electrical resistivity and conductivity distribution. The study identified a clayey sand horizon which constitutes a good aquifer zone. The study reveals in, comparison, that during the dry season, all layer resistivities are high with low depth while during the wet season; all layer resistivities are low with high depth. Also, conductivity during the wet season is high at high depth than conductivity which is low at low depth during the dry season. The study concluded that, in water exploration, drilling of water should be done during the dry season in other to locate the exact depth of water.
\end{abstract}

\section{DOI:10.46481/jnsps.2020.128}

Keywords: Aquifer, Conductivity, lithology, Resistivity, Seasonal Effect

Article History :

Received: 14 August 2020

Received in revised form: 23 September 2020

Accepted for publication: 06 October 2020

Published: 15 November 2020

(c)2020 Journal of the Nigerian Society of Physical Sciences. All rights reserved. Communicated by: O. J. Abimbola

\section{Introduction}

Water that flows on the earth's surface due to rainfalls, finds its way to the river while others sink into the ground. Plants use some while some evaporate and return to the atmosphere. Water found below and above the ground is termed groundwater and surface water respectively. Groundwater found below

${ }^{*}$ Corresponding author tel. no: +2347032261146

Email address: coker.joseph@oouagoiwoye.edu.ng (J. O. Coker) the ground, percolate the soil, and can be collected in wells, tunnels, or drainage galleries [1].

Water extracted from the ground has three main uses: agriculture (irrigation), domestic consumption (source of drinking) as a source of potable water,and industrially with little, or no purification before it can be used for achieving sustainable development).Groundwater has a larger storage capacity than surface water [2]. Groundwater is very useful; an estimation of about 2 billion people in urban and rural communities world- 
wide depends on groundwater for daily consumption [3]. The need for the exploration of a sedimentary aquifer in the study area is necessary to identify potential groundwater aquifer and this could be achieved by a combination of two detailed integrated geophysical methods, which are the electrical resistivity and electromagnetic methods.

Oladunjoye et al. [4] investigated the localized nature of groundwater occurrence in Ogbomoso North to solve the scarcity of potable water in the area by employing the very low frequency electromagnetic and electrical resistivity methods.The data acquisition involved four electrical resistivity profiles and five VLF-EM carried out parallel to the two major azimuths in the study area. The result obtained reveals the usefulness of combining electromagnetic and electrical resistivity methods to locate suitable sites for water borehole drilling.

Coker et al. [5] employed resistivity method for groundwater potential comparison in Oke - Badan, data acquisition was done in the peak of a dry season - March and the peak of a wet season - July. The major rocks in the study area are pegmatite, quartzite, and quartz schist. The investigated area delineated five subsurface layers. The value of apparent resistivity ranges from $13.76 \Omega m$ and $4828.26 \Omega m$ during the dry season while during the wet season; it was low ranges between $11.6 \Omega m$ and $2878.2 \Omega m$ with high depth to basement rocks varies from $0.2 \mathrm{~m}$ and $91.3 \mathrm{~m}$. The same pattern was delineated for both the seasons with an increase in thickness hence; a good groundwater potential zone was identified at the southwestern part of the weathered layer maps.

\subsection{Location and the Geologic Settings of the Study Area}

Ogun state geology is made of sedimentary and basement complex terrains, with intercalations of argillaceous sediment [6]. Figure 1 shows the sedimentary rock of the state which consists of Abeokuta formation underlying by basement complex terrain, above by Ewekoro, Oshosun and Ilaro formations follow by the Benin formation [6]. Ijebu Ife the study area, is situated within Ijebu East of Ogun state with latitude $6.78^{\circ} \mathrm{N}$ of the equator and longitude $4.03^{\circ} \mathrm{E}$ of the Greenwich meridian. It lies within the sedimentary terrain on the eastern part of the Dahomey basin with a population of 5733 [7]. Ogun State has two seasons such as the rainy season from March to October and the dry season for the remaining part of the year, though there is always a very low rainfall in August and it is referred to as the "August break". A climate in Ijebu Ife is tropical with much more rainfall during the rainy season. The topography of Ijebu Ife has a wide area of undulating lowlands, Figure 2, tropical of the coastal sedimentary terrain of southwestern Nigeria. Water drains out of Ijebu Ife passing through tributaries which flows into the Ogun River. Ogun River discharges into the Lagos lagoon which flows into the Atlantic Ocean. The availability of water for domestic, agriculture, and industries (small scale industries) is a function of seasonality since groundwater yield is generally associated with seasonal varieties of factors such as climatic conditions, weather, etc. The geological terrains of Ijebu Ife contribute to the fluctuation of groundwater level and aquifer during the wet and dry season, though Ogun State with

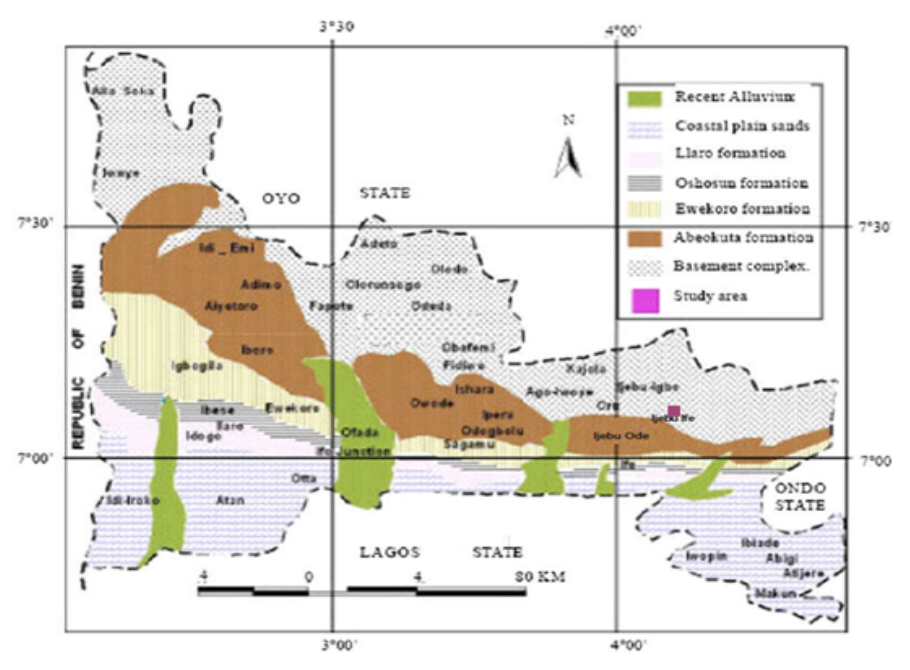

Figure 1. Geological map of Ogun State [6].

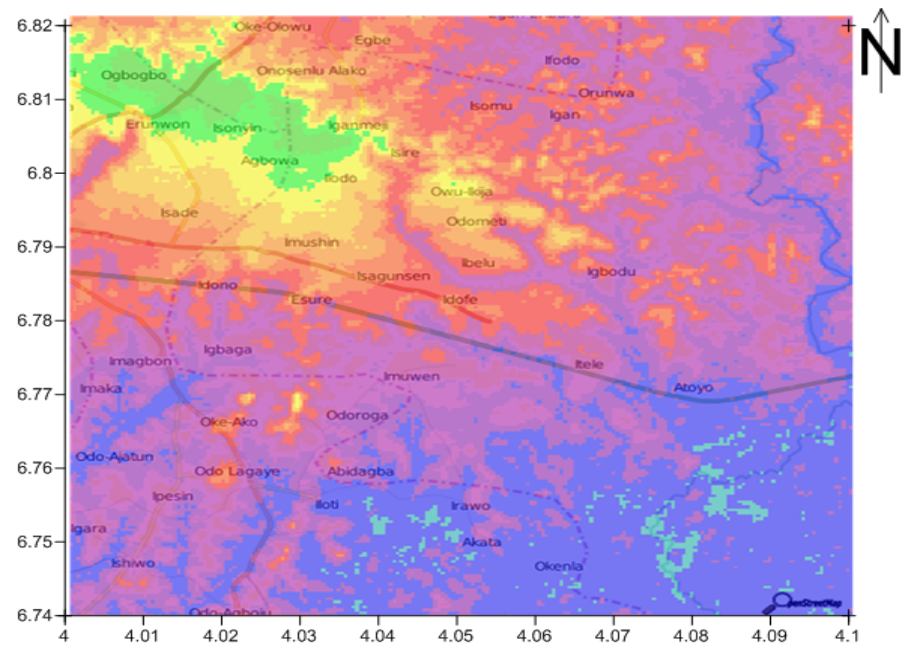

Figure 2. Topographical map of Ijebu Ife [8].

monsoon climate is characterized with high rainfall and high evaporation. The size of the field is $8000 \mathrm{sqm}$.

\section{Materials and Method}

The two major techniques conducted for the fieldwork are electromagnetic method and the dipole - dipole method. The electromagnetic method makes use of very low frequency, primarily as a reconnaissance tool as large areas of land can be rapidly covered, with other geophysical methods combine with it. For this work, a dipole-dipole array was combined with the VLF-EM method to explore potential groundwater aquifer in Ijebu Ife.

A total of 10 traverses were covered for both wet and dry seasons within Ijebu Ife, Ogun State as shown on the location map (Figure 3). Each traverse has a length of $500 \mathrm{~m}$ and at $10 \mathrm{~m}$ fixed spacing measured using a measuring tape. An ABEM WADI VLF transmitter was used to measure and generate data on the field. The data were subject to filtering using Karous and 


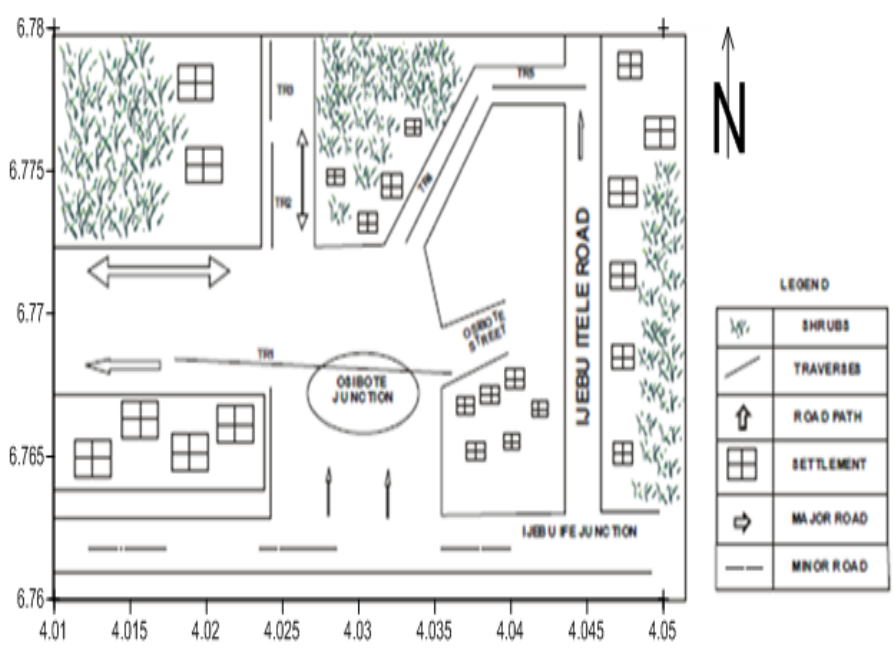

Figure 3. Location map showing VLF - EM traverse.

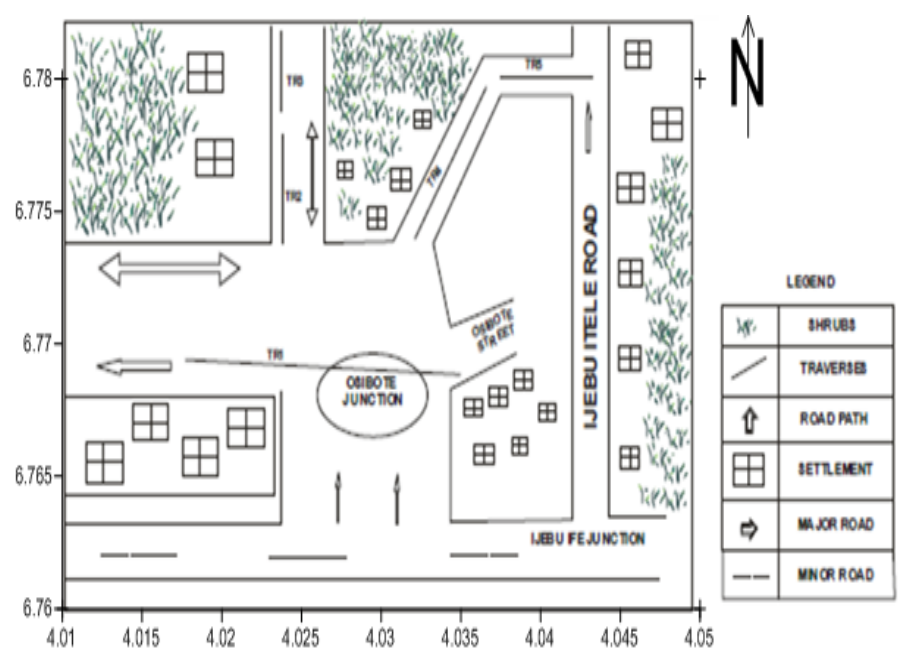

Figure 4. Location map showing dipole - dipole traverse.

Fraser filter to increase the signal to noise ratio and enhance the response signatures.

Dipole - dipole on the other hand is one of the widely used resistivity methods because of its low EM coupling between the current and potential circuits. A total of 10 traverses were investigated in both seasons with each traverse length covered $160 \mathrm{~m}$ of distance and at $5 \mathrm{~m}$ fixed spacing of the current and potential electrode measured from measuring tape. Data were generated on the field using ABEM SAS1000 Terrameter as shown on the location map (Figure 4). Subsequently, reading on the field was taking every $5 m$ and the data was processed with DIPROFWIN software to obtain pseudosection.

\section{Results and Discussion}

\subsection{Discussion of results during the dry season}

The results of the processed 2D resistivity imaging are shown in colour format in form of pseudosections (Figure 5a - e). The geoelectric section is indicative of the resistivity characterization of the subsurface as presented in Table 1 .
Table 1. Table of geoelectric parameter for electrical resistivity (Dipole Dipole) of Traverse 1 to 5 in dry season.

\begin{tabular}{lcccc}
\hline Traverse & Layer & $\begin{array}{c}\text { Geoelectric } \\
\text { Layer }\end{array}$ & $\begin{array}{c}\text { Relativity } \\
(\Omega m)\end{array}$ & $\begin{array}{c}\text { Depth } \\
(m)\end{array}$ \\
\hline \multirow{3}{*}{1} & 1 & Top Soil & $35-488$ & $0-3$ \\
& 2 & Clayey Sand & $85-774$ & $3-11$ \\
& 3 & Sandy Clay & $152-218$ & $5-25$ \\
2 & 1 & Top Soil & $126-1946$ & $0-3$ \\
& 2 & Clayey Sand & $228-1580$ & $3-7$ \\
& 3 & Sandy Clay & $1502-25092$ & $7-25$ \\
3 & 1 & Top Soil & $260-2105$ & $0-3$ \\
& 2 & Clayey Sand & $292-3258$ & $3-11$ \\
& 3 & Sandy Clay & $500-11410$ & $7-25$ \\
4 & 1 & Top Soil & $190-886$ & $0-3$ \\
& 2 & Clayey Sand & $190-2673$ & $3-10$ \\
& 3 & Sandy Clay & $543-5008$ & $7-25$ \\
5 & 1 & Top Soil & $495-886$ & $0-3$ \\
& 2 & Clayey Sand & $495-2324$ & $3-11$ \\
& 3 & Sandy Clay & $19-1071$ & $5-25$ \\
\hline
\end{tabular}

The electrical resistivity profile for traverse one which is $120 \mathrm{~m}$ in length found at the south western part and its measured apparent resistivity pseudosection is presented in Figure $5 \mathrm{a}$. The overview of the inverted resistivity profile of this profile line is described below. Layer one reveals resistivity value between $35 \Omega m-488 \Omega m$ and extends to a depth of about $3 m$ beneath the surface. Layer two is inferred as the weathered layer with the value of resistivity from $85 \Omega m-774 \Omega m$ at a depth of 3-11 $m$ thus highly indicating the presence of clayey sand soils. The third layer has a resistivity values that range from $152 \Omega m-218 \Omega m$ at a depth of about $5 m-25 m$ is indicative of a groundwater deposit, the resistivity value is very low thus, interpreted as sandy clay.

The traverse line 2 is $140 \mathrm{~m}$ in length at the north-western part with the measured apparent resistivity pseudosection shown in Figure 5b. Layer 1 is interpreted as topsoil has a resistivity value ranging from $126 \Omega m-1946 \Omega m$ from the surface to $3 m$ depth. Layer 2 inferred as the weathered layer interpreted as clayey- sand has a value of resistivity between $228 \Omega m$ and $1580 \Omega m$ from a depth of about 3-7 $\mathrm{m}$. The third layer interpreted as sand extends from the depth range of about 7-25 m and has a value of resistivity between $1502 \Omega \mathrm{m}$ and $25092 \Omega \mathrm{m}$.

The electrical resistivity profile for traverse line 3 occurred in the northwestern area. A Dipole-dipole array was used for this traverse line which measures $140 \mathrm{~m}$. The measured apparent resistivity pseudosection is presented in Figure 5c. The first layer interpreted as topsoil with resistivity value between $260 \Omega m$ and $2105 \Omega m$ from the surface to $3 m$ depth. Layer 2 is inferred as the weathered layer, interpreted as clayey- sand with resistivity values between $292-3258 \Omega m$ from a depth range of about 3-11 $\mathrm{m}$. The Third layer interpreted as sand has resistivity values between 500 and $11410 \Omega m$.

The traverse line 4 is $140 \mathrm{~m}$ length found at the Northeastern area with a measured apparent resistivity pseudosection shown in Figure 5d. Layer 1 is the topsoil with resis- 
tivity value between $190 \Omega m$ and $886 \Omega m$ from the surface to $3 \mathrm{~m}$ depth. Layer 2 inferred as the weathered layer, interpreted as clayey sand has resistivity values between $190 \Omega m$ and $2673 \Omega \mathrm{m}$. Layer 3, interpreted as sand extends from a depth range of about $7-25 \mathrm{~m}$ and has resistivity values between 543 $-5008 \Omega m$.

The traverse line 5 is found at the Northeastern area with a traverse length of $140 \mathrm{~m}$. Layer 1 is the topsoil with values of resistivity ranges from $495-886 \Omega m$ from the surface to $3 \mathrm{~m}$ depth. Layer 2 is the weathered layer, inferred as clayey sand with values of resistivity between $495-2324 \Omega m$ with a range of depth between $3-11 \mathrm{~m}$. Layer 3 inferred as sand extends from a depth range of about $5-25 \mathrm{~m}$ with values of resistivity between 19 and $1071 \Omega m$.

Figure 6a shows the pseudosection VLF results generated from the interpreted data along with profile 1 . The real component varies from $-60 \%$ to $+20 \%$. The section indicates possible anomalous zones that range from -10 to $+10 \mathrm{mmho} / \mathrm{m}$ (conductive region) with lateral distance of $200-350 \mathrm{~m}$ that could favor groundwater exploration. These zones were indicated by the high conductive zone in yellow to red colors. However, the low conductive region identified in green to blue colors at both ends of the traverse indicates that the subsurface has similar conductivity values along the profile.

Figure $6 \mathrm{~b}$ shows the pseudo-section VLF results generated from the interpreted data along with profile 2 . The real component varies from $-60 \%$ to $+20 \%$. From the section, the subsurface is indicative of similar conductivity values that range from -10 to $+10 \mathrm{mmho} / \mathrm{m}$. However, the pocket of high conductivity regions was observed at lateral distance of 60,200, 320, and $450 \mathrm{~m}$ respectively.

Figure $6 \mathrm{c}$ shows the pseudo-section VLF results generated from the interpreted data along with profile 3 . The real component varies from $-60 \%$ to $+20 \%$. From the section, the subsurface is indicative of conductivity values that range from -10 to $+15 \mathrm{mmho} / \mathrm{m}$. However, no distinct conductivity regions were observed along the traverse.

Figure 6d shows the pseudo-section VLF results generated from the interpreted data along with profile 4 . The real component varies from $-60 \%$ to $+20 \%$. The conductivity of this section varies between -25 to $+10 \mathrm{mmho} / \mathrm{m}$. From the section, no distinct conductivity region is delineated. However, the moderate conductivity values between +5 to $+10 \mathrm{mmho} / \mathrm{m}$ identified along the profile are suggestive of the weathered layer indicated in light yellow color.

Figure 6e shows the pseudo-section VLF results generated from the interpreted data along with profile 5 . The real component varies from $-60 \%$ to $+20 \%$. The conductivity of this section varies between -25 to $+20 \mathrm{mmho} / \mathrm{m}$. From the section, the conductive zones (between +10 to $+20 \mathrm{mmho} / \mathrm{m}$ ) identified at lateral distance of 150 to $200 \mathrm{~m}$ and 270 to $370 \mathrm{mmho} / \mathrm{m}$. These zones are suspected to be weathered and fractured layers from depth of about 20 to $60 \mathrm{~m}$ in yellow to red color along with the profile that could favor groundwater exploration.

\subsection{Discussion of Results at Wet Season}

The lithologic unit as interpreted from the inverted electrical resistivity profile is presented in Table 2 and Figure $7(a-e)$ for traverse $1-5$ respectively. Traverse 1 covered $120 m$ length

Table 2. Table of geoelectric parameter for electrical resistivity (Dipole Dipole) of Traverse 1 to 5 during the wet season.

\begin{tabular}{lcccc}
\hline Traverse & Layer & $\begin{array}{c}\text { Geoelectric } \\
\text { Layer }\end{array}$ & $\begin{array}{c}\text { Relativity } \\
(\Omega m)\end{array}$ & $\begin{array}{c}\text { Depth } \\
(\mathrm{m})\end{array}$ \\
\hline \multirow{4}{*}{1} & 1 & Top Soil & $28-310$ & $0-5$ \\
& 2 & Clayey Sand & $70-300$ & $0-20$ \\
& 3 & Sandy Clay & $35-120$ & $5-25$ \\
2 & 1 & Top Soil & $140-500$ & $10-25$ \\
& 2 & Clayey Sand & $534-1400$ & $5-25$ \\
& 3 & Sandy Clay & $1900-23721$ & $5-25$ \\
3 & 1 & Top Soil & $84-500$ & $0-25$ \\
& 2 & Clayey Sand & $500-2468$ & $0-25$ \\
& 3 & Sandy Clay & $370-4486$ & $5-25$ \\
4 & 1 & Top Soil & $120-450$ & $0-10$ \\
& 2 & Clayey Sand & $500-1200$ & $0-25$ \\
& 3 & Sandy Clay & $1300-4445$ & $5-25$ \\
5 & 1 & Top Soil & $200-259$ & $0-25$ \\
& 2 & Clayey Sand & $50-150$ & $5-25$ \\
& 3 & Sandy Clay & $18-42$ & $12-25$ \\
\hline
\end{tabular}

found at the south-west of the location (Figure 7a). The resistivity value of layer one ranges between 28 and $319 \Omega m$ interpreted as the topsoil with a varying depth of $0-5 \mathrm{~m}$.Layer two is inferred as the weathered layer, interpreted as clayey sand has a resistivity ranging from $70-300 \Omega m$ with a varying depth of $0-20 \mathrm{~m}$. Layer three resistivity value is between 35 and 120 $\Omega m$ at $0-25 m$ interpreted as sandy clay.

The traverse line 2 is found in the North-west with a length of $140 \mathrm{~m}$ (Figure 7b). Layer one resistivity is between 140 and $500 \Omega m$ at $10-25 m$ depth interpreted as the topsoil. The second layer resistivity is between 534 and $1400 \Omega m$ at $5-25$ $m$ depth inferred as the weathered layer, with lithology as wet sand. The third layer has resistivity value between 1900 and $23721 \Omega m$ at $5-25 m$ depth interpreted as sand.

The traverse line 3 is $140 \mathrm{~m}$ length, located in the northwest (Figure 7c). Layer one has resistivity value ranging $84-$ $500 \Omega m$ at $0-25 m$ depth which is the topsoil. The second geoelectric layer inferred as the weathered layer has resistivity values between $500-2468 \Omega m$ at $0-25 m$ depth interpreted as wet sand. The third layer, has a resistivity value is between 370 - $4486 \Omega m$ at $5-25 m$ depth interpreted as sand.

The traverse 4 line is $140 \mathrm{~m}$ length north-west (Figure 7d). Layer one resistivity is between $120-450 \Omega m$ at $0-10 m$ depth interpreted as topsoil. The second geoelectric layer inferred as the weathered layer, interpret as wet sand has a resistivity range of $500-1200 \Omega m$ at $0-25 m$ while the third layer, interpreted as sand has a resistivity range of $1300-4445 \Omega m$ at $5-25$ $m$. The profile line for traverse 5 is $140 \mathrm{~m}$ length located in the northeast (Figure 7e). The first layer resistivity values range between $200-259 \Omega m$ at $0-25 m$ depth, interpreted as topsoil, the second layer inferred as the weathered layer, clayey 

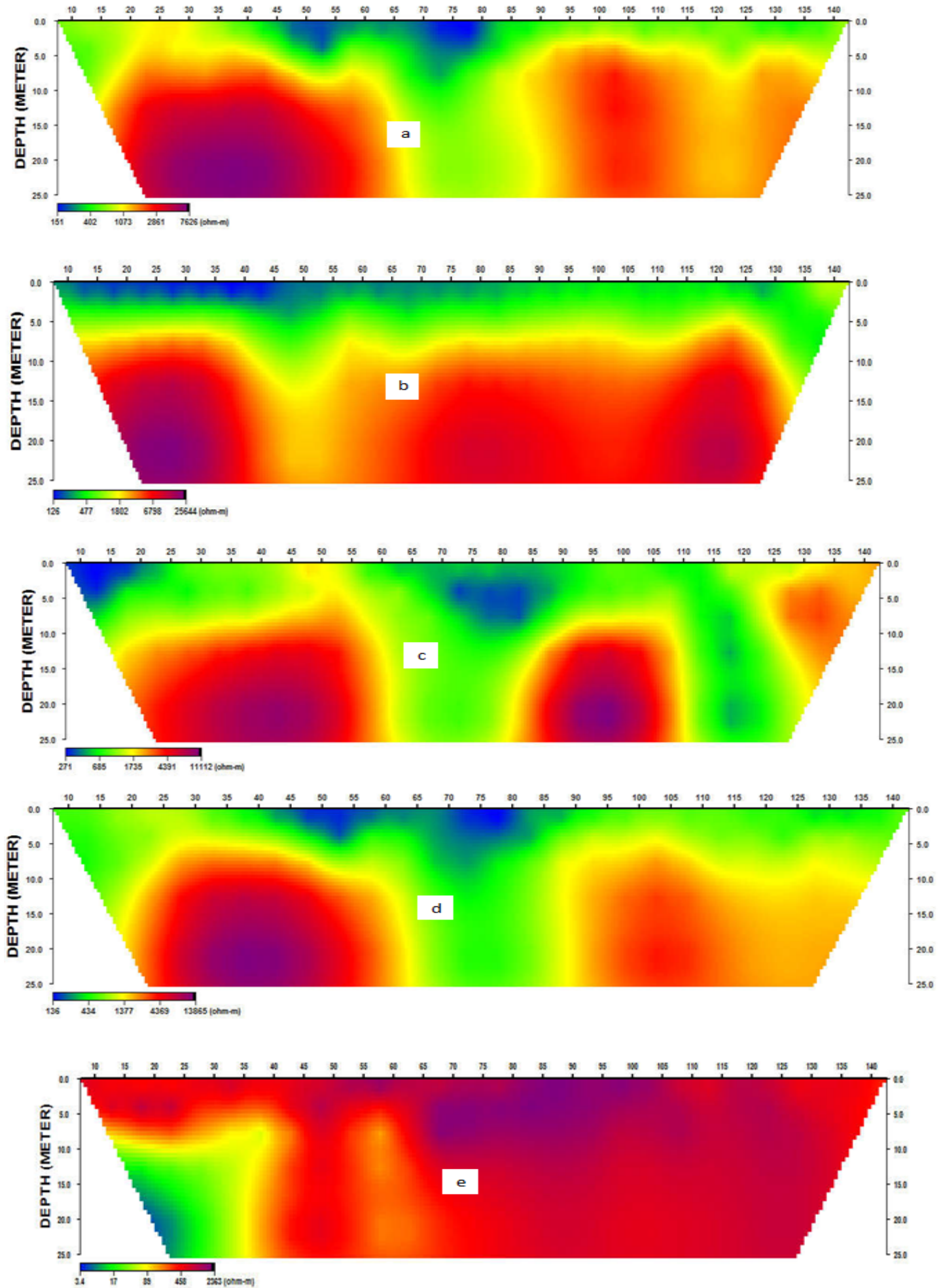

Figure 5. 2D Dipole - Dipole Resistivity profile for Traverses a to e during the Dry Season.

sand with resistivity value ranges between 50 - $150 \Omega m$ while the third layer, interpreted as sandy clay with resistivity value between $18-42 \Omega m$ at $12-25 m$ depth.

Figure $8(\mathrm{a}-\mathrm{e})$ shows the pseudo-section VLF results generated from the interpreted data along with profile $1-5$ during the wet season.
On profile 1 (Figure 8a), the real component varies from $60 \%$ to $+20 \%$. The section indicates a possible anomalous zone (conductive zone) suspected to be fractured zone at a lateral distance of 290-370 $\mathrm{m}$ that could favour groundwater exploration. This zone is indicated by highly conductive values between +10 to $+30 \mathrm{mmho} / \mathrm{m}$ in red colour along with the profile. 

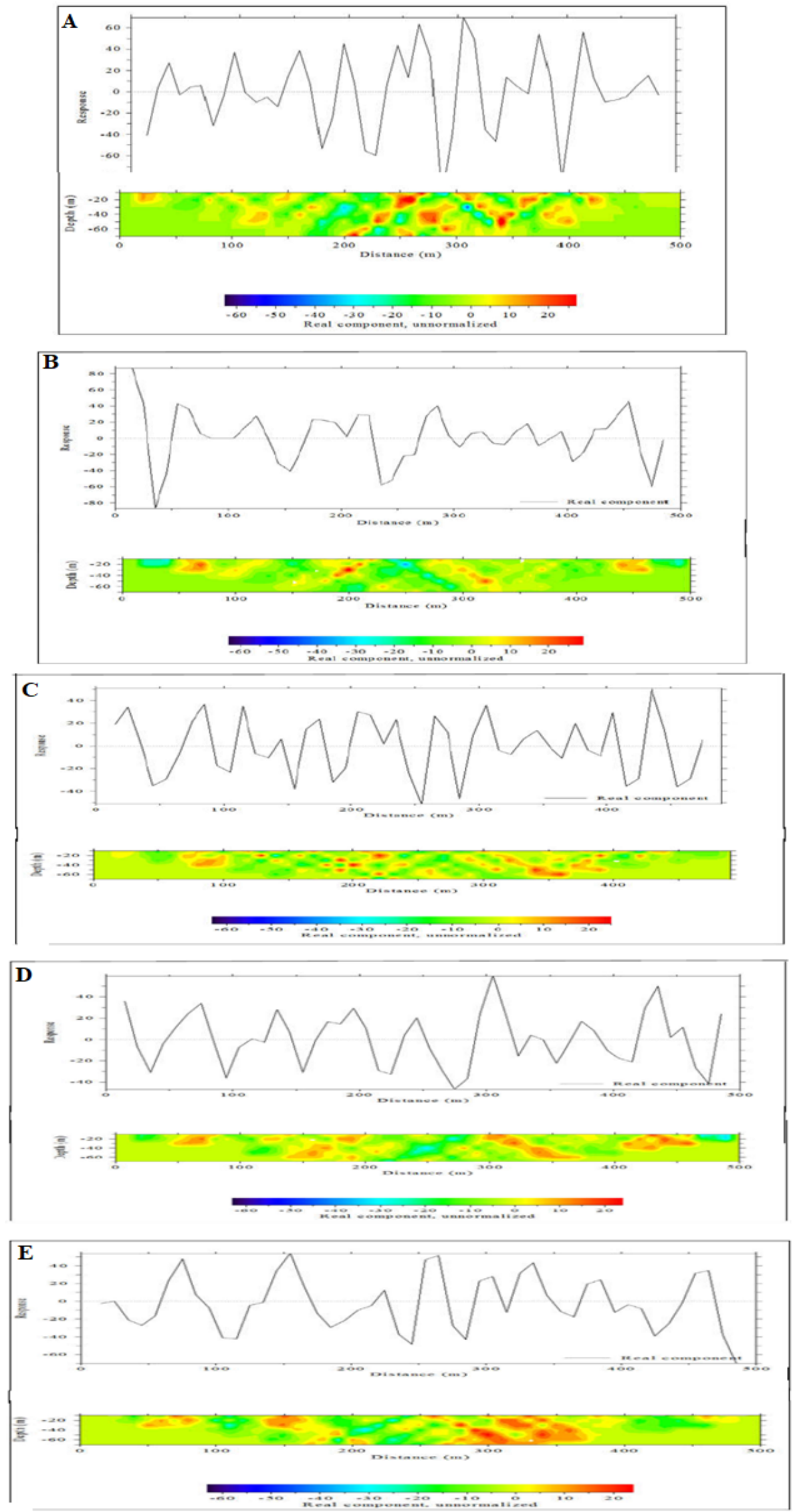

Figure 6. 2D Pseudosection of the VLF along Traverse 1 at Dry Season. 

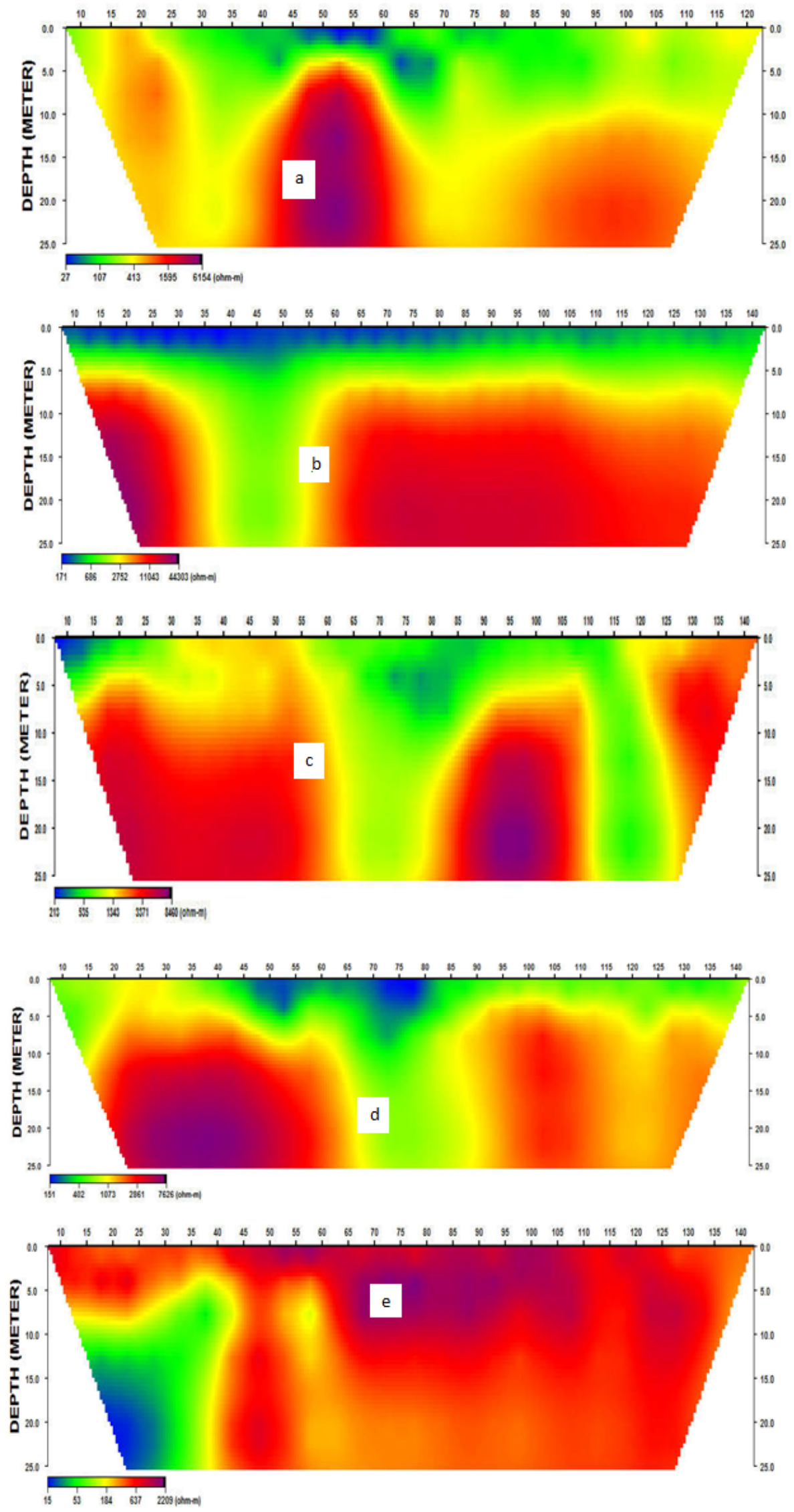

Figure 7. 2D Dipole - Dipole Resistivity Profile for Traverse 1 during Wet Season. 

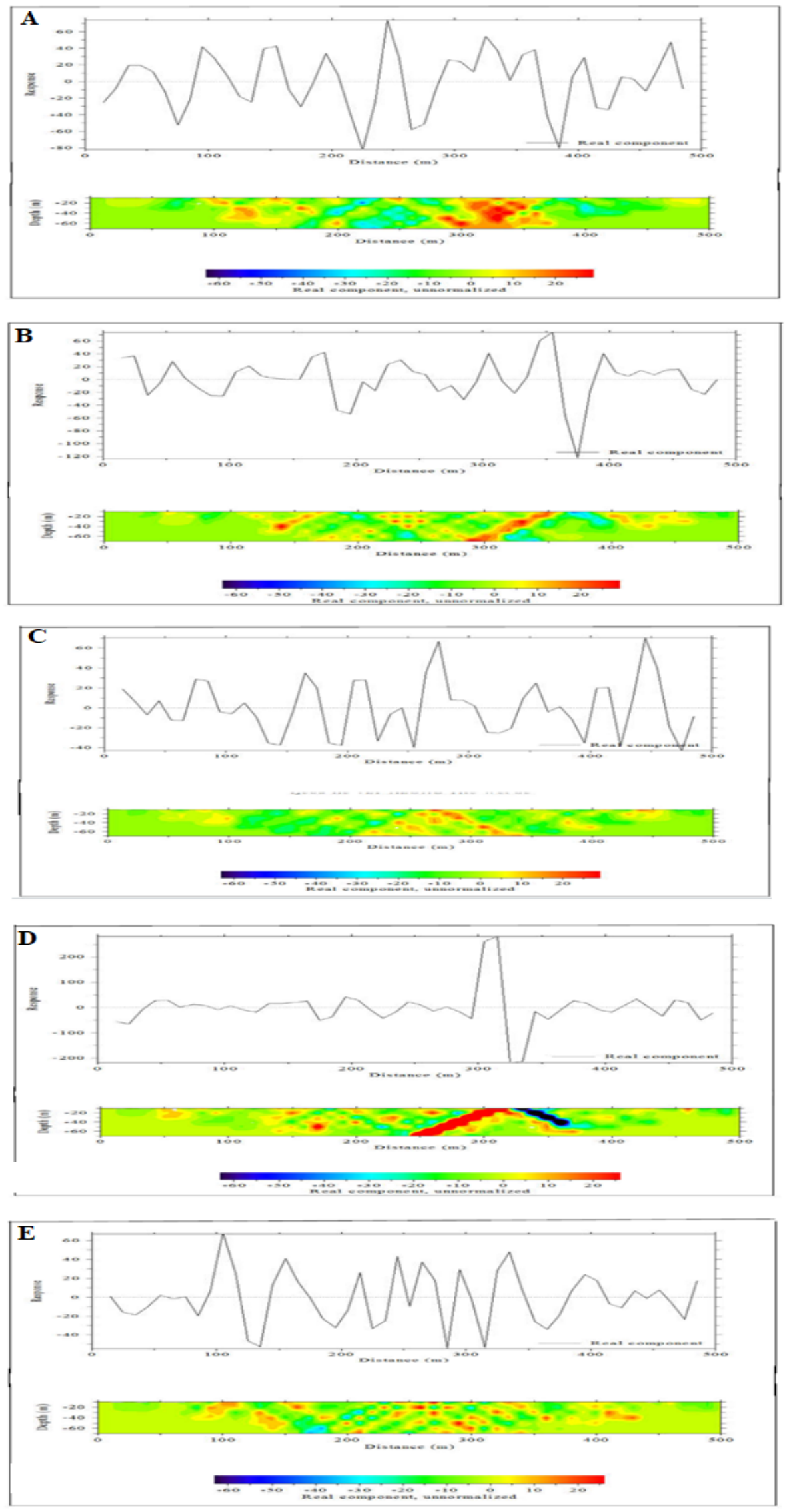

Figure 8. 2D VLF pseudosection along with profile 1 - 5 during wet season. 
On profile 2 (Figure $8 \mathrm{~b}$ ), the real component varies from $60 \%$ to $+20 \%$. The conductivity of this section varies between -25 to $+25 \mathrm{mmho} / \mathrm{m}$. From the section, the conductive zones (between +15 to $+25 \mathrm{mmho} / \mathrm{m}$ ) was identified at a lateral distance of $300-350 \mathrm{~m}$ form a depth of about $20-60 \mathrm{~m}$. This zone is suspected to be a fractured layer in yellow to red colour along with the profile that could favour groundwater exploration.

On profile 3 (Figure 8c), the real component varies from $60 \%$ to $+20 \%$. The conductivity of this section varies between -20 to $+15 \mathrm{mmho} / \mathrm{m}$. From the section, a conductive zone is identified at a lateral distance of $210-340 \mathrm{~m}$ that could favour groundwater exploration. This zone is indicated by high conductive values between +10 to $+15 \mathrm{mmho} / \mathrm{m}$ suspected to be a fractured layer from a depth of about 20 to $60 \mathrm{~m}$ in yellow to light red colour along with the profile.

Along with profile 4 (Figure 8d), the real component varies from $-60 \%$ to $+20 \%$. The section indicates a possible anomalous zone (conductive zone) suspected to be a fractured zone at lateral distance of $250-350 \mathrm{~m}$ that could favour groundwater exploration. This zone is indicated by the highly conductive value in red colour along with the profile.

On profile 5 (Figure 8e), the real component varies from $60 \%$ to $+20 \%$. From the section, the subsurface is indicative of conductivity values that range from -10 to $+15 \mathrm{mmho} / \mathrm{m}$. However, no distinct conductivity regions were observed along the traverse.

\subsection{Correlation of Results for Dry and Wet Season along Pro- files 1 to 5}

The comparison of the layer resistivity of Table 1 and Table 2 with Figures 5 to 7 reveals the following:

On profile 1, the resistivity values are higher in the dry season than the wet season. Hence, the aquifer thickness of layer 2 in the wet season (Figure 7a) is $20 \mathrm{~m}$ higher than that of the dry season which is $11 \mathrm{~m}$ (Figure 5a).

On profile 2 , the resistivity values are higher in the dry season than the wet season. Hence, the aquifer thickness for layer 2 in the wet season (Figure 7b) is $25 \mathrm{~m}$ higher than that of the dry season which is $7 m$ (Figure $5 b$ ).

On profile 3, the resistivity values are higher in the dry season than the wet season. Hence, the aquifer thickness for (layer 2) in the wet season (Figure 7c) is $25 \mathrm{~m}$ higher than that of the dry season which is $11 \mathrm{~m}$ (Figure 5c).

On profile 4, the resistivity values are higher in the dry season than the wet season. Hence, the aquifer thickness of layer 2 in the wet season (Figure 7d) is $25 \mathrm{~m}$ higher than that of the dry season which is $10 \mathrm{~m}$ (Figure $5 \mathrm{~d}$ ). The layers resistivity values for the dry season is higher than that of the wet season.

On layer 5, the resistivity values are higher in the dry season than the wet season. Hence, the aquifer thickness of layer 2 in the wet season (Figure 7e) is $25 \mathrm{~m}$ higher than the dry season which is $11 \mathrm{~m}$ (Figure 5e).

\section{Conclusion}

In Ijebu-Ife during the dry and wet seasons; the study reveals high resistivity values for all layers with low depth and corresponding low conductivity during the dry season. The study also reveals low resistivity values for all layers with high depth and corresponding high conductivity during the wet season.

During the dry season, the resistivity value of the second layer in Ijebu-Ife is high $(292 \Omega m-3258 \Omega m)$ maximum and $(85 \Omega m-774 \Omega m)$ minimum compared with that of the wet season $(500 \Omega m-2468 \Omega m)$ maximum and $(50-150 \Omega m)$ minimum. The thickness of the aquifer is low during the dry season $(3-11 \mathrm{~m})$ maximum depth and $(3-7 \mathrm{~m})$ minimum depth compared with during the wet season $(0-25 \mathrm{~m})$ maximum and $(0-20 \mathrm{~m})$. According to Coker et al. [5] during the wet season, high depth and low resistivity values were recorded which could be a result of the influence of pore water.

\section{Acknowledgments}

We thank the referees for the positive enlightening comments and suggestions, which have greatly helped us in making improvements to this paper.

\section{References}

[1] A. A. Alabi, R. Bello, A. S. Ogungbe \& H. O. Oyerinde, "Determination of groundwater potential in Lagos State University, Ojo, using geoelectric methods (vertical electrical sounding and horizontal profiling)" Report and Opinion, 5(2010) 68.

[2] O. L. Ademilua \& A. O. Talabi, "The use of Combine Geophysical survey methods for groundwater prospecting. In a typical basement complex terrain; a case study of Ado-Ekiti, southwest Nigeria" Research Journal in Engineering and Applied Science, 1(2012) 363.

[3] E. Mygatt, "Eco-Economy Fudicators - Water Resources" https://www.earthpolicy.org/index.php?/indicator/C57/, (2006).

[4] M. Oladunjoye, M. Adabanija \& O. Adeboye, "Groundwater prospecting and exploration in a low potential hard rock aquifer: Case study of Ogbomoso North" Journal of Environment \& Earth Science, 3(2013).

[5] J. O. Coker, M. A. Oladunjoye \& N. O. Adebisi, (2017). "Seasonal Comparative study of groundwater potential in Oke- Badan Estate, Akobo" Nigerian Journal of Advancement in Engr. Tech. Management and Applied Science, 4(2017) 01.

[6] J. O. Coker, V. Makinde, A. O. Mustapha \& J. K. Adesodun, "Electrical Resistivity Imaging for Foundation Failure Investigation at Remo Secondary School, Sagamu, SouthWestern Nigeria" International Science and Investigation Journal, 2(2013) 40.

[7] P. R. Ikhane, K. O. Omosanya, A. A. Akinmosin \& A. B. Odugbesan, (2012): "Electrical Resistivity Imaging (ERI) of Slope Deposits and Structures in Some Parts of Eastern Dahomey Basin" Journal of Applied Sciences, 12(2012) 716 .

[8] Floodmap, "Elevation of Ijebu - Ife, Nigeria. Retrieved from Flood Map" https://www.floodmap.net, (2020). 